\title{
TP53*1 Allele
}

National Cancer Institute

\section{Source}

National Cancer Institute. TP53*1 Allele. NCI Thesaurus. Code C97240.

Human TP53*1 allele is located in the vicinity of 17 p13.1 and is approximately $19 \mathrm{~kb}$ in length. This allele, which encodes cellular tumor antigen p53*1 protein, is involved in apoptosis and tumor suppression. This variant exhibits a coding change from a proline at amino acid 72 to an arginine, which may affect the activity and stability of the encoded protein. 